\title{
Table of international conventions and documents
}

(N.B. Conventions and Documents not included in text (and having no page references) but used in research are listed separately under individual main headings as appropriate)

\section{INTERNATIONAL CONVENTIONS}

Anti-Counterfeiting Trade

Agreement (ACTA)

Berne Convention for the

Protection of Literary and

Artistic Works

83, 96, 182

Biological Diversity Convention

Energy Charter Treaty (ECT) ......... 28, $80-81,100,132,145$

Human Rights and Fundamental Freedoms Convention, Protocol No. 1

ICSID Convention (Settlement of Investment Disputes) see index entry

Intellectual Property in Respect of Integrated Circuits Treaty .....83, 84

Multilateral Investment Guarantee Agency, Convention Establishing

Paris Convention for the Protection of Industrial Property 12,47 $82-3,182$, 217-18, 219

Protection of Performers, Producers of Phonograms and Broadcasting Organizations, International Convention for ..... 83 Subsidies and Countervailing Measures (SCM) Agreement 145
Technical Barriers to Trade (TBT)

Agreement 145, 218-19

UN Resolution on the Permanent Sovereignty over Natural Resources 37

UN, Statute of the International

Court of Justice

12, UNCTAD, Havana Charter for an International Trade Organization 101

UPOV Convention (International Convention for the Protection of New Varieties of Plants)

Vienna Convention on the Law of Treaties (VCLT) ........11-12, 13, 18, $89,93,208$

WHO Framework Convention on

Tobacco Control (FCTC) .........201, 203, 212-13

World Trade Organization (WTO)

Amendment of the TRIPS

Agreement 151

Doha Declaration on the TRIPS agreement and public health adoption 48

Doha Declaration, Implementation-related Issues and Concerns

GATT Uruguay Round, Multilateral Trade Negotiations, Trade-related Aspects of Intellectual Property Rights 49,52 
Implementation of Paragraph 6 of The Doha Declaration on the TRIPS Agreement and Public Health 48

Rules and procedures governing the settlement of disputes, Annex 2

TRIPS Agreement see index entry Working Group on the Interaction between Trade and Competition Policy, Korea Communication 50

World Trade Organization,

Marrakesh Agreement Establishing

General Agreement on Trade in Services (GATS), Annex 1B ......135

General Agreement on Tariffs and Trade (GATT), Annex $1 \mathrm{~A}$

Legal Instruments, Annex 1C-

Results of the Uruguay

Round $2,48,141,156$

Marrakesh Declaration

TRIMS (Trade-Related Investment Measures) see index entry

\section{Documents not Included in Text but Used in Research}

Declaration of the Government of the Democratic and Popular Republic of Algeria Concerning the Settlement of Claims by the Government of the United States of America and the Government of the Islamic Republic of Iran, 19 January 1981, 1 Iran-U.S. Cl. Trib. Rep. 9.

UNESCO Convention on the Protection and Promotion of the Diversity of Cultural Expressions (opened for signature 20 October 2005 , entered into force $18 \mathrm{March}$ 2007, available at http://www. unesco.org/ (accessed 9 October 2014).

\section{BILATERAL \\ INTELLECTUAL PROPERTY AGREEMENT}

United States of America and

Nicaragua $181-2$

\section{BILATERAL INVESTMENT TREATIES}

Azerbaijan and Finland 140

Australia and Egypt .................129-30

Australia and Hong Kong .........205-8, 210, 213-20

Australia and Pakistan ...................129

Austria and Malaysia ..................... 21

Barbados and Germany ................. 92

Belgium/Luxembourg and Burundi . 58

135 Canada and Argentina ................... 17

Canada and Costa Rica .................141

Canada and Lebanon ......................142

Canada and Philippines .................132

Canada and Ukraine .......................130

Canada and Uruguay ......................130

Canada and Venezuela ...................152

Croatia and Canada ........................130

Ethiopia and Israel ..................... 18-19

France and Argentina ................163-4

France and Singapore ..................... 11

Germany and Argentina ................167

Germany and Barbados .................. 92

Germany and Bosnia and Herzegovina ..............................129

Germany and Guyana ..................... 94

Germany and Pakistan ..................3, 13

Germany and Thailand ................... 90

Ghana and Benin ........................... 15

Hong Kong and Australia .........205-8,

210-20

India and Ghana ............................ 15

Japan and Vietnam .........143, 150, 185

Korea and Japan ..............143, 150, 185

Mexico and Cuba ..........................143

Mongolia and Singapore ................ 21

Netherlands and Brazil ................... 11

Netherlands and Pakistan ............... 11

Nicaragua and Netherlands ... 194, 199

Pakistan and Germany .................3, 13

Peru and Germany .......................... 18 
South Korea and Chile $.64-5$

South Korea and United Kingdom . 11

Spain and Argentina 91

Switzerland and Pakistan 136

Switzerland and Paraguay

Thailand and Germany 138

United Arab Emirates and Malaysia .130

United Kingdom and Albania .. 92

United Kingdom and Antigua and Barbuda 10

United Kingdom and Bahrain .....92-3

United Kingdom and Ecuador ....... 11

United Kingdom and Malaysia ....... 21

United Kingdom and South Korea . 11

United Kingdom and Yemen

United States of America and Bahrain 10,149

United States of America and Argentina .............28, 138, 164, 172

United States of America and Cameroon $.128-9$

United States of America and Egypt 130

United States of America and Jamaica

United States of America and Jordan 149,182

United States of America and Nicaragua

United States of America and Panama

United States of America and Uruguay $130,143,150$

United States of America and Mongolia 17

United States of America and Romania $133,138,171$

United States of America and Turkey 13,130

\section{Treaties not Included in Text but Used in Research}

\section{China and Germany}

Agreement between the People's Republic of China and the Federal Republic of Germany on the Encouragement and Reciprocal Protection of
Investments, signed 1 December 2003, entered into force 11 November 2005, available at http://www.unctad.org/ (accessed 27 January 2014).

\section{Germany and Turkey}

Treaty between the Federal Republic of Germany and the Republic of Turkey Concerning the Reciprocal Promotion and Reciprocal Protection of Investments, signed 20 June 1962 , entered into force 5 December 1965, available at http://unctad.org/ (accessed 27 January 2014).

\section{Germany and Venezuela}

Tratado entre la República Federal de Alemania y la República de Venezuela para la Promoción y Protección Recíproca de Inversiones, signed 14 May 1996, entered into force 16 October 1998, available at http://www. unctadxi.org/ (accessed 27 January 2014).

\section{Indonesia and India}

Agreement between the Government of the Republic of Indonesia and the Government of the Republic of India for the Promotion and Protection of Investments, signed 10 February 1999 , entered into force 22 January 2004, available at http:// unctad.org/ (accessed 27 January 2014).

\section{Netherlands and Philippines}

Agreement between the Kingdom of the Netherlands and the Republic of the Philippines for the Protection of Investments, signed 27 February 1985, entered into force 1 October 1987, available at http://unctad.org/ (accessed 27 January 2014). 


\section{Sri Lanka and India}

Agreement between the

Government of the Democratic

Socialist Republic of Sri Lanka

and the Government of the

Republic of India for the

Promotion and Protection of

Investment, signed 22 January

1997, entered into force 13

February 1998, available at http://unctad.org/ (accessed 27 January 2014).

\section{Switzerland and Kuwait}

Accord entre la Confédération Suisse et l'Etat du Koweït concernant la promotion et la protection réciproque des investissements, signed 31 October 1998, entered into force 17 December 2000, available at http://unctad.org/ (accessed 9 October 2014).

\section{Thailand and India}

Agreement between the

Government of the Kingdom of Thailand and the Government of the Republic of India for the Promotion and Protection of Investments, signed 10 July 2000 , entered into force 13 July 2001 , available at http://unctad.org/ (accessed 27 January 2014).

MODEL BILATERAL INVESTMENT TREATIES

Asian-African Legal Consultative Committee

Canada $80,106,143$

China ... 10

France 10,90

Germany 10,103

Switzerland 137

United Kingdom $80,87,129$

United States of America ..........54, 67, $80,91,106,131$

\section{BILATERAL TRADE AGREEMENTS}

India and Singapore 65

Japan and Singapore 132,150

\section{Agreement not Included in Text but Used in Research}

Agreement between the United States of America and the Socialist Republic of Vietnam on Trade Relations, signed 13 July 2000 , entered into force 10 December 2001, available at http://www.usvtc.org/ (accessed 27 January 2014).

\section{FREE TRADE AGREEMENTS}

Australia and United States 74, 132

CETA (Comprehensive Economic and Trade Agreement between Canada and the European Union) ......................167, 189, 227

Canada and Chile ..........................132

Chile and Mexico .............................130

Dominican Republic and Central America (CAFTA) .................... 74

EFTA States and Singapore .........94-5

European Community and Algeria 167

European Community and Morocco

MERCOSUR

Mexico and Nicaragua .............130-31

Morocco and United States ..... 74, 151

NAFTA $28,38,39,41$, $58,81,85,91-2$, $100,132,202,221$

NAFTA Free Trade Commission 105-7, 109, 111-12, 171

South Korea and Chile 64

Trans-Pacific Partnership Agreement (TPPA) 160,221

United States and Chile 74,150

United States of America and Oman 150

United States and Singapore ..... 74, $75,150-51,189,226$ 
United States of America and South Korea (KORUS FTA) 182

\section{NATIONAL LEGISLATION}

Australia, Tobacco Plain Packaging Act 2011 203-4

Belgian Constitution 37,245

German Constitution .245

Italian Constitution 37,245

United States Constitution 37

United States, Semiconductor Chip Protection Act (SCPA) 84

Uzbekistan, Health Decree 30 202, 260

\section{OECD (ORGANISATION \\ FOR ECONOMIC \\ CO-OPERATION AND \\ DEVELOPMENT)}

Draft Convention on the Protection of Foreign Property

Economic Impact of Counterfeiting and Piracy' 2, 153-4

Guidelines for Multinational Enterprises

'Multilateral Agreement on Investment' 75,150

'Report to the Negotiating Group on Intellectual Property' 13

\section{Documents not Included in Text but Used in Research}

OECD (1998), 'Report to the Negotiating Group on Intellectual Property', Negotiating Group on the Multilateral Agreement on Investment (MAI), 14 January 1998, DAFFE/MAI/IP(98)1.

OECD (1997), 'Report to the Negotiating Group on Intellectual Property', Negotiating Group on the Multilateral Agreement on Investment (MAI), 4 November 1997, DAFFE/MAI(97)32.
UNCTAD (UNITED

NATIONS CONFERENCE

ON TRADE AND

DEVELOPMENT)

'Admission and Establishment' .77, 224

Bilateral Investment Treaties 1995-2006 126,178

'Expropriation' 39

Host Country Operational Measure

Incentives ................................. 127-8

Investor-State Dispute Settlement and Impact on Investment Rulemaking 42

Most-Favoured-Nation Treatment $86,91,99,100$

National Treatment 79-80, 82

Tax Incentives and Foreign Direct Investment 128

Transfer of Technology 145

UNEP-UNCTAD Capacity Building Task Force, Organic Agriculture and Food Security in Africa 118,252

World Investment Report 2014 ........... 3

\section{Documents not Included in Text but Used in Research}

UNCTAD, World Investment Report 2013: Global Value Chains: Investment and Trade for Development, 2013, available at http://www.unctad.org/ (accessed 27 January 2014).

\section{MISCELLANEOUS DOCUMENTS}

Australia, Parliamentary Debates ...204 Australia, Tobacco Plain Packaging Bill 2011: Explanatory Memorandum .203

Australia, Tobacco Plain Packaging Bill 2011 - Exposure Draft 204,264

International Meeting on Cooperation and Development 
International Law Commission, Responsibility of State for Internationally Wrongful Acts ....161

United States Department of State, Investment Climate Statement Nicaragua

United States Federal Register United States Trade Representative, 2013 Out-of-Cycle Review of Notorious Markets 196 64
United States Trade Representative, Nicaragua 196

U.S. Bilateral Investment Treaty

Program 181

WHO, Australia Plain Packaging Legislation Submission .......212-13

WHO Report on the Global Tobacco Epidemic 201, 203 World Customs Organization, Customs and IPR Report ... 155, 258 